\title{
Canadian Banking Industry Profitability: Exploring the Relevance of Two Competing Hypotheses
}

\author{
Abayomi Oredegbe ${ }^{1}$ \\ ${ }^{1}$ Department of Business Administration, University College of the North, Manitoba, Canada \\ Correspondence: Abayomi Oredegbe, Department of Business Administration, University College of the North, \\ Manitoba, Canada. E-mail: aoredegbe@ucn.ca
}

Received: February 4, 2020

Accepted: March 12, 2020

Online Published: March 18, 2020

doi:10.5539/ijef.v12n4p67

URL: https://doi.org/10.5539/ijef.v12n4p67

\begin{abstract}
This study investigates the Canadian banking industry profitability and seeks to determine if there is evidence of market power hypothesis (MPH) and/or efficiency structure hypothesis (ESH) in the industry. Using GMM and data from 2006 to 2018, it finds no support for the structure-conduct-performance (SCP) component of MPH. However, evidence of relative market power (RMP) in the industry reflects partial support for MPH, implying that banks that offer differentiated products are able to exercise market power, increase market share, and achieve better profitability. The lack of support for X-efficiency (ESX) and scale efficiency (ESS), which are components of ESH, indicates no support for the ESH. The finding that QLH holds in the industry suggests the level of competition is inadequate and that managers in the industry exhibit suboptimal behaviour. Therefore, increasing the level of competition in the industry will stimulate managerial effectiveness. Findings relating to the control variables show that spread impedes profitability, whereas capitalization and the joint influence of spread and liquidity risk have facilitating effects. Credit risk is immaterial to profitability however, the effect of economic growth can be positive. This study provides a better understanding of the industry, which is important to managers, regulators, and policy makers. The robustness checks affirm the consistency of the findings and policy implications.
\end{abstract}

Keywords: Canadian banking, concentration, efficiency, market power, profitability, quiet life hypothesis

\section{Introduction}

Driven by changes in regulation, technology, and market conditions, the banking industry continues to evolve (Gunes \& Yilmaz, 2016; Kuzucu, 2015; Allen \& Engert, 2007). In Canada, the Porter Commission played an important role in shaping the industry's regulatory framework and liberalization (Savage, 2014). In addition, adjustments to the Bank Act of 1967 and subsequent amendments in the 1980s and 1990s led to more changes, enabling the industry to respond to globalization and technological innovation (Daniel, 2003). Although the regulatory framework reveals interest in the industry's soundness, inadequate understanding of the industry could lead to wrong perception of the industry's soundness and contribution to the economy. Given that the industry's contribution is integral to economic growth and development (Menicucci \& Paolucci, 2016), and the fact that profitability is a crucial indicator of the industry's performance (International Monetary Fund, 2006), it is important to examine the relationship between the industry's structure, efficiency, and profitability through the lenses of market power hypothesis (MPH) and efficiency structure hypothesis (ESH). The investigation provides useful insights to managers in the industry and policy makers seeking to discern which of the two hypotheses prevails in the industry. If MPH dominates, it would suggest that the industry confers market power to banks, such that high profitability is possible by colluding and/or by offering differentiated products and services (Casu \& Giradone, 2006; Berger, 1995). However, if ESH prevails, it would indicate that the industry's profitability is due to improved efficiency, which may cause the industry's concentration to increase as less efficient banks lose market share to efficient banks and/or exit the industry (Casu \& Giradone, 2006; Berger, 1995). While studies on banking industry structure, efficiency, and profitability abound, findings vary. Some (e.g., Qayyum, Mehmood, Kasheer, \& Haider, 2018; Nabieu, 2013; Ye, Xu, \& Fang, 2012) show partial support for MPH by providing evidence of SCP or RMP in the industry. However, there are studies (e.g., Alhassan, Tetteh, \& Brobbey, 2016; Ayadi \& Ellouze, 2013; Chortareas, Garza-Garcia, Girardone, 2010) that provide partial support for the ESH by finding X-efficiency (ESX) or scale efficiency (ESS) in the industry. In some studies (e.g., Bucevska \& Misheva, 
2017; Tregenna, 2009), the evidence reflects full support for the MPH or the ESH. Nonetheless, studies such as Simatele, Mishi, and Ngonyama (2018), Sharma, Gounder, and Xiang (2013), Kapopoulos and Siokis (2005), and Berger (1995) show concurrent presence of MPH and ESH components. These inconsistencies in findings suggest the need for an empirical study with more insight. A good understanding of MPH and ESH is important to managers in the industry seeking to improve profitability. It is also important to policy makers trying to avoid wrong policy decisions. Studies on the Canadian banking industry are inconsistent and not contemporary. For example, analyzing data from 1972 to 1974 , Short (1979) seems to indicate that profitability is due to market power, but the period investigated encompasses early changes in the industry's evolution. On the other hand, Shaffer (1993) suggests that the industry is perfectly competitive, which the study considers similar to findings in Nathan and Neave (1989). The view that the industry is perfectly competitive could be due to investigating periods in the 1980s when the 1980 Bank Act amendment that changed the industry's competitive landscape took effect. Based on data from 1994 to 2001, Claessens and Laeven (2004) examination of banking industry around the world show that the Canadian banking industry is monopolistically competitive. Also, using data from 2000 to 2006, Allen and Engert (2007) insinuate no evidence of collusive behavior in the industry, but the study notes that the industry reflects monopolistic competition. In general, studies on Canada are insufficient, not current, and differ in findings. In addition, they give no clear understanding of how the industry's structure affects profitability. Furthermore, existing studies provide no clear information to help discern if MPH and/or ESH holds in the industry, which are inquiries addressed in this study. Since banking industry structure changes with time (Mendes \& Rebelo, 2003), wrongly proclaiming MPH and/or erroneously declaring that ESH holds in the industry could lead to incorrect policies, strengthening the rationalization for a new empirical study on Canada. By focusing on MPH and ESH, this study sheds light on the industry's structure, allowing regulators and policy makers to discern the impact of each of the two hypotheses on profitability prior to instituting new measures or initiatives. This study has six sections. Following the first section (i.e., Introduction), the next section (Section 2) provides a review of related literature on banking industry structure, efficiency and profitability. Section 3 describes the methodology and data. Section 4 discusses the findings. Section 5 presents the robustness checks that affirm the findings. The study concludes with policy implications and suggestions for future research.

\section{Literature Review}

Studies on banking industry structure apply non-structural and structural approaches. The nonstructural studies (e.g., Rodriguez, Bolivar, \& Reyes, 2018; Demirel \& Hatirli, 2017; Bikker, Shaffer, \& Spierdijk, 2012; Aktan \& Masood, 2010; Gischer \& Stiele, 2008; Casu \& Giradone, 2006) rely on Bresnahan-Lau model, Lener index, and the Panzar-Rosse model. Typically, studies of this nature identify the industry as monopolistically competitive, however, some characterize it as perfectly competitive (e.g., Shaffer, 1993; Nathan \& Neave, 1989), oligopoly (e.g., Babic, Zildzovic, \& Loncar, 2015; Mensi, 2010), or monopoly (e.g., Mustafa \& Toci, 2017). The structural approach relies on proxies such as Herfindahl-Hirschman Index (HHI) and concentration ratio of $n$ firms $\left(\mathrm{CR}_{\mathrm{n}}\right)$ to elucidate the level of competition in the industry (Nguyen, 2019; Bikker, Shaffer, \& Spierdijk, 2012; Berger, Demirguc-Kunt, Levine, \& Haubrich, 2004). Conceptually, studies (e.g., Bucevska \& Misheva, 2017; Alhassan, Tetteh, \& Brobbey, 2016; Al-Muharrami \& Matthews, 2009) that apply the structural approach highlight two competing hypotheses (i.e., market power hypothesis [MPH]; efficiency structure hypothesis [ESH]) in discuss relating to banking industry profitability. The MPH assumes that industry structure determines profitability, whereas the ESH presumes that efficiency results in low costs and better profitability (Alhassan, Tetteh, \& Brobbey, 2016; Mensi \& Zouari, 2011). Within the MPH is the structure-conduct-performance (SCP) construct and the relative market power (RMP) conjecture. The SCP construct presupposes that industry concentration affects conduct and shapes performance (Hamid, 2017), suggesting that the absence of competition in highly concentrated industry creates the environment where firms collude to achieve higher level of profitability (Lelissa \& Kuhil, 2018; Berger et al., 2004). On the other hand, the RMP conjecture asserts that firms with differentiated products are able to increase market share and power, resulting in better profitability (Hamid, 2017). The ESH discerned by Demsetz (1973) posits that efficient firms can enlarge in market share and attain higher profitability than less efficient firms (Bucevska \& Misheva, 2017). Similar to the MPH, the ESH has two suppositions. As espoused in Lelissa and Kuhil (2018, p. 35), Seelanatha (2010, p. 23) and Fu and Heffernan (2009, p. 42), the first is "X-efficiency" (ESX), which supports the notion that firms with efficient operations or better management achieve cost advantage, lager market share, and better profitability. In essence, the higher the efficiency, the larger will be the market share and market power, leading to an increase in the industry's concentration and high profitability for the efficient firm. The second is the "scale efficiency" (ESS) proposition, which maintains that if banks have similar management and comparable technology, the bank operating closer to the most productive scale size will generate better profitability, suggesting that profitability is the result of operating at the appropriate operational scale. Studies on banking industry structure, efficiency, and profitability 
have generated conflicting findings. Some (e.g., Hamid, 2017; Qayyum, Mehmood, Kasheer, \& Haider, 2018; Nabieu, 2013) focus on MPH by investigating SCP and RMP in the industry. Although Nabieu (2013) shows the presence of SCP, findings in Hamid (2017) and Qayyum et al. (2018) reveal support for RMP. Noting no support for MPH (i.e., SCP \& RMP), Dabbous \& Nassereddine (2017) and Bucevska and Misheva (2017) provide evidence in favour of the ESH, signifying that profitability is due to efficient operations, not collusive behaviors. The inference is that banks with better management and operational scale are able to curtail costs, enlarge market share, and increase profitability (Casu \& Giradone, 2006). On the contrary, some studies indicate partial support for MPH. A classic example is Ye, Xu, and Fang (2012) findings that show no evidence of SCP or ESH. However, its strong support for RMP signals that banks with differentiated products and services are able to increase profits by exercising market power. In addition, there are studies such as Bhatti and Hussain (2010) and Al-Muharrami and Matthews (2009) that show support for SCP, demonstrating that concentration in the industry creates the environment where banks collude to increase profitability. Furthermore, single country studies (e.g., Simatele, Mishi, \& Ngonyama, 2018; Alhassan, Tetteh, \& Brobbey, 2016; Doyran, 2012; Ye, Xu, \& Fang, 2012; Tregenna, 2009; Lu, Fung, \& Jiang, 2007) differ in findings, which could be due to differences in methodology, country characteristics and economic conditions, regulation, and the period of study. Notably, studies that examined the industry in the same country have produced conflicting findings. For example, Doyran (2012) and Tregenna (2009) differ in findings relating to the banking industry in US. Also, Ye, Xu, and Fang (2012) and Lu, Fung, and Jiang (2007) deliver contrasting results concerning the Chinese banking industry. In the case of Canada, while Short (1979) finds that market power leads to higher profitability, Nathan and Neave (1989) and Shaffer (1993) suggest that the industry is perfectly competitive. On the other hand, Allen and Engert (2007) conclude that the industry is monopolistically competitive. Understandably, some of the studies on Canada investigated periods in the early stages of change in the industry, however, others examined periods when changes to the Bank Act took effect. The justification for a Canadian study stems from comprehending that findings relating to other countries are contradictory and may not be relevant to Canada. In addition, outcome of studies from European Union and US may not reflect the prudential nature of the Canadian banking industry. Furthermore, the small number of studies on the Canadian banking industry are dated and inconsistent in findings, which could expose the industry to wrong policy decisions. Investigating the MPH and ESH reveals information that managers in the industry would find pertinent when attempting to augment profitability. Additionally, this study contributes to discussions that provide policy makers better understanding of the dominant construct in the industry. If MPH prevails, policies should guard against consolidation, preventing the concentration of the industry and/or collusive behavior (Ajlouni, 2010). On the other hand, if ESH prevails, policies should ensure that efficient banks continue to minimize costs and increase market share, even though it could lead to an increase in the concentration of the industry (Fare, Grosskopf, Maudos, \& Tortosa-Ausina, 2015; Seelanatha, 2010)

\section{Methodology and Data}

Studies (e.g., Bhatti \& Hussain, 2010; Molyneux \& Forbes, 1995) test the underlying assumption relating to MPH and ESH using the structural approach model similar to the one shown below:

$$
\Pi_{i t}=\beta_{0}+\beta_{1} H H I_{t}+\beta_{2} M S_{i t}+\sum_{i=3}^{n} \beta_{i} Z_{i t}+e_{i t}
$$

The notation $\Pi_{\mathrm{it}}$ is the profitability of bank $i$ in period $t$. The profitability variable is often proxied by either return on assets (ROA) or return on equity (ROE) (Antoun, Coskun, \& Georgievski, 2018; Sharma, Gounder, \& Xiang, 2013). $\mathrm{HHI}_{\mathrm{t}}$ is the industry's concentration in period $t$. Herfindahl-Hirschman Index (HHI) is the proxy for the industry's concentration (Bikker, Shaffer, \& Spierdijk, 2012; Berger et al., 2004). $\mathrm{MS}_{\mathrm{it}}$ is the market share of bank $i$ in period $t . Z_{\mathrm{it}}$ is the vector of additional control variables that include bank specific, industry specific and macroeconomic variables $i$ in period $t . \beta_{0}$ is the constant term, whereas $e_{i t}$ is the random error. As noted in (Bhatti \& Hussain, 2010), traditional SCP is confirmed if $\beta_{1}>0$ and $\beta_{2}=0$, suggesting that concentration is associated with the industry's profitability. The efficiency construct is ascertained if $\beta_{1}=0$ and $\beta_{2}>0$, indicating that efficient firms are able to increase market share and profitability. While the pioneer model (Model 1) provides the foundation for understanding MPH and ESH, Sathye and Sathye (2004) and Berger (1995) remarks show that the market share (MS) variable may reflect effects that are not associated with efficiency, implying that MS is an incorrect proxy for efficiency. Similar to Berger (1995) and Fu and Heffernan (2009), the underlying model that captures the two efficiency measures in this study is:

$$
\Pi_{i t}=\beta_{0}+\beta_{1} H H I_{t}+\beta_{2} M S_{i t}+\beta_{3} E S X_{i t}+\beta_{4} E S S_{i t}+\sum_{i=5}^{n} \beta i Z i+e_{i t}
$$

The model incorporates the respective conjectures of two competing hypotheses (i.e., MPH \& ESH). Studies (e.g., Simatele, Mishi, \& Ngonyama, 2017; Ye, Xu, \& Fang, 2012; Mensi \& Zouari, 2010; Seelanatha, 2010) 
signify that banks could minimize costs by using less inputs to generate outputs, or by managerial effectiveness. As such, it is common to use technical efficiency (TE) or pure technical efficiency (PTE) as the X-efficiency (ESX) measure in conjunction with SE, which is the scale efficiency (ESS) measure. X-efficiency (ESX) indicates that banks with superior management or technology would produce outputs at minimum costs (Lelissa \& Kuhil, 2017). Rather than infer cost efficiency (CE) from TE or PTE, this study adopts the approach in Bucevska \& Misheva (2017), directly incorporating CE in the model to reflect X-efficiency (ESX) along with SE as the scale efficiency (ESS) measure. The modified model with ROA as profitability variable is:

$$
R O A_{i t}=\beta_{0}+\beta_{1} H H I_{t}+\beta_{2} M S_{i t}+\beta_{3} C E_{i t}+\beta_{4} S E_{i t}+\sum_{i=5}^{n} \beta i Z i+e_{i t}
$$

Banks become cost efficient by being technically and allocatively efficient, minimizing costs for a given level of outputs to increase profitability (Isik \& Hassan, 2002). In addition, becoming scale efficient by operating at optimum scale size minimize costs, contributing to higher profitability (Behname, 2012; Tregenna, 2009). Similar to Oredegbe (2020), the industry's CE and SE were determined using input oriented Data Envelopment Analysis (DEA), which is a nonparametric approach requiring no price information. Additionally, the intermediation approach, which is the common approach for input and output selection is relied on in the selection of the three inputs (i.e., deposits, employment, non-interest expense) and two outputs (i.e., loans and net-interest income). Studies that have used DEA efficiency scores include Guillen, Rengifo, and Ozsoz (2014) and Seelanatha (2010). Although studies vary in methodology and estimation approach, the generalized method of moments (GMM) estimation technique is prevalent. It deals with potential endogeneity bias, and mitigates erroneous estimation (Ullah, Akhtar, \& Zaefarian, 2018; Alhassan, Tetteh, \& Brobbey, 2016). Furthermore, it is a good estimator in situations where the explanatory variables are not decisively exogenous (Garza-Garcia, 2012). This study uses the single equation instrumental variable regression with GMM as the estimator, robust weighting matrix, and reports findings at 95\% confidence level. Some studies (e.g., Bhatti \& Hussain, 2010; Tregenna, 2009) incorporate bank and industry specific variables in the model, however there are studies (e.g., Dabbous \& Nassereddine, 2017; Mensi \& Zouari, 2010) that include a combination of bank specific, and industry and macroeconomic variables in the model. The additional control variables in the model in this study consist of bank and industry specific variables such as credit risk (LLPTL), spread (SPREAD), liquidity risk (LOTD), and capitalization (EQTA). In addition, it includes economic growth (i.e., change in GDP per capita [CGDPPC]) as the macroeconomic variable. Also, an interaction term (SPREAD*LOTD) is included in the model to assess the joint impact of spread and liquidity risk. The model with bank and industry specific and the macroeconomic variable is:

$$
\begin{gathered}
R O A_{i t}=\beta_{0}+\beta_{1} H H I_{t}+\beta_{2} M S_{i t}+\beta_{3} C E_{i t}+\beta_{4} S E_{i t}+\beta_{5} L L P T L_{i t}+\beta_{6} S_{P R E A D_{i t}}+ \\
B_{7} C G D P P C_{t}+\beta_{8} L O T D_{i t}+\beta_{9} E Q T A_{i t}+\beta_{10} S P R E A D^{*} L O T D_{i t}+e_{i t}
\end{gathered}
$$

The data is from the Canadian Bankers Association database, annual financial statements of banks, and Conference Board of Canada. To remove the impact of inflation, variables in Canadian dollars have been adjusted using consumer price index (CPI) with 2015 chosen as the base year. As noted in Berger (1995) and Fu \& Heffernan (2009), for MPH to hold, coefficients of variables reflecting SCP and RMP have to be greater than zero (i.e., $\beta_{1}>0, \beta_{2}>0, \beta_{3}=0$, and $\beta_{4}=0$ ). Similarly, for ESH to prevail, coefficients of variables reflecting $\mathrm{X}$-efficiency (ESX) and scale efficiency (ESS) have to be greater than zero (i.e., $\beta_{1}=0, \beta_{2}=0, \beta_{3}>0$ and $\beta_{4}>0$ ). In addition, support for a unique instance of market power, which is known as Hicks' (1935) "quiet life" hypothesis (QLH) (Fare et al., 2015, p. 160; Fu \& Heffernan, 2009, p. 43; Berger \& Hannan, 1998, p. 456) is explored using the two tests below (Model $3 \&$ Model 4).

$$
\begin{gathered}
C E_{i t}=\beta_{0}+\beta_{1} H H I_{t}+\beta_{2} M S_{i t}+\sum_{i=3}^{n} \beta i Z i+e_{i t} \\
S E_{i t}=\beta_{0}+\beta_{1} H H I_{t}+\beta_{2} M S_{i t}+\sum_{i=3}^{n} \beta i Z i+e_{i t}
\end{gathered}
$$

If concentration and market share variables have statistically significant negative influence on CE (i.e., the proxy for X-efficiency [ESX]) and SE (i.e., the proxy for scale efficiency [ESS]), support for QLH is evident (Fu \& Heffernan, 2009; Berger \& Hannan, 1998). It would suggest that market power allows managers in the industry to exhibit slack behavior, and shirk responsibilities to increase revenue and/or minimize costs (Fare et al., 2015). Similarly, to carry out confirmation tests for the ESH, the two tests below (Model $5 \&$ Model 6) are necessary.

$$
\begin{aligned}
& H H I_{t}=\beta_{0}+\beta_{I} C E_{i t}+\beta_{2} S E_{i t}+\sum_{i=3}^{n} \beta i Z i+e_{i t} \\
& M S_{i t}=\beta_{0}+\beta_{1} C E_{i t}+\beta_{2} S E_{i t}+\sum_{i=3}^{n} \beta i Z i+e_{i t}
\end{aligned}
$$

The CE and SE variables denoting X-efficiency (ESX) and scale efficiency (ESS) should have positive and statistically significant effects on concentration (HHI) and market share (MS). 


\section{Results and Discussion}

For insight on the structure of the industry, HHI, which is the proxy for industry concentration was determined by finding the sum of the square of the market share of firms in the industry (Ferreira, 2013; OECD, 2010). The mean HHI is 1894 when the HHI information is based on total assets, but it is 1879 when the data is based on deposits (Table 1). The industry's concentration based on assets (i.e., $\mathrm{HHI}_{\mathrm{a}}$ ) increased by 4.1 percent in the study period, signifying that larger banks are investing more in assets than smaller banks, which could allow them to increase access to customers and compete in the global financial markets. On the other hand, the increase in the industry's concentration when the concentration level is based on deposit (i.e., $\mathrm{HHI}_{\mathrm{d}}$ ) is 2.9 percent, signalling that large banks have not increased market share by much, or that smaller banks are gaining market share in the industry. The latter seems plausible as $\mathrm{HHI}_{d}$ declined in the last two years (Table 1). Overall, the $\mathrm{HHI}_{\mathrm{a}}$ and $\mathrm{HHI}_{\mathrm{d}}$ trends in Figure 1 reveal an increase in the industry's concentration in the study period. Using the HHI classification in US Department of Justice and the Federal Trade Commission (2010, p. 19), it is reasonable to conclude that the Canadian banking industry is "moderately concentrated." This buttresses the outlook in Allen and Engert (2007), which shows that a handful of banks control more than 90 percent of the assets in the industry. Given that a concentrated industry could still be competitive (Owen \& Pereira, 2018; Claessens \& Laeven, 2004), finding that the Canadian banking industry is somewhat concentrated may not indicate that competition is lacking in the industry. The industry faces competition from non-banks (e.g., insurance), virtual banks, and emerging financial tech industry, suggesting that it is competitive despite the indication that it is somewhat concentrated (Department of Finance Canada, 2016). The efficiency trends in Figure 2 show decline in all areas of efficiency measure. This could be due to the concentration of the industry as studies indicate that high concentration hinders efficiency (OECD, 2010; Berger \& Hannan, 1998).

Table 1. Canadian banking industry concentration (HHI)

\begin{tabular}{lll}
\hline & $\mathrm{HHI}_{\mathrm{a}}$ & $\mathrm{HHI}_{\mathrm{d}}$ \\
\hline 2006 & 1857 & 1828 \\
2007 & 1847 & 1841 \\
2008 & 1889 & 1866 \\
2009 & 1868 & 1880 \\
2010 & 1875 & 1880 \\
2011 & 1907 & 1874 \\
2012 & 1876 & 1859 \\
2013 & 1887 & 1878 \\
2014 & 1900 & 1875 \\
2015 & 1928 & 1919 \\
2016 & 1942 & 1924 \\
2017 & 1920 & 1918 \\
2018 & 1933 & 1881 \\
\hline Change in HHI $(\%)$ & 4.1 & 2.9 \\
Mean & 1894 & 1879 \\
Median & 1889 & 1878 \\
Std. Dev. & 30 & 29 \\
Minimum & 1847 & 1828 \\
Maximum & 1942 & 1924 \\
\hline
\end{tabular}

Note. $\mathrm{HHI}_{\mathrm{a}}=$ Herfindahl-Hirschman Index based on assets; $\mathrm{HHI}_{\mathrm{d}}=$ Herfindahl-Hirschman Index based on deposits.

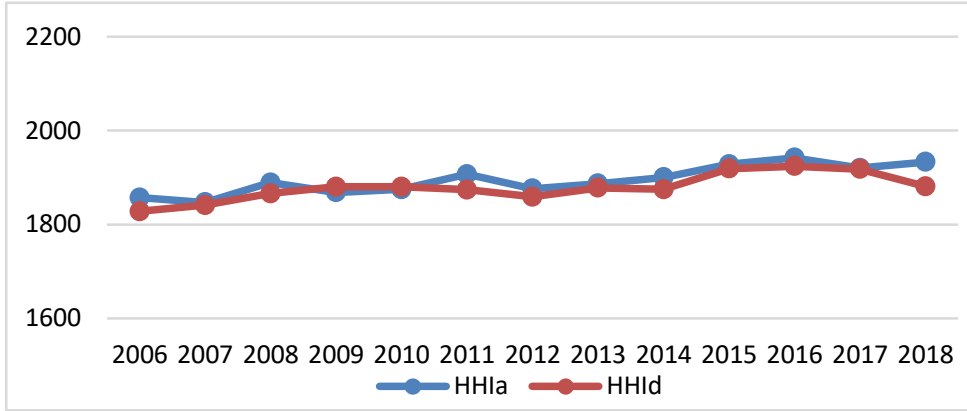

Figure 1. Trends in Herfindahl-Hirschman Index based on assets $\left(\mathrm{HHI}_{\mathrm{a}}\right)$ and Herfindahl-Hirschman Index based on deposits $\left(\mathrm{HHI}_{\mathrm{d}}\right)$ 


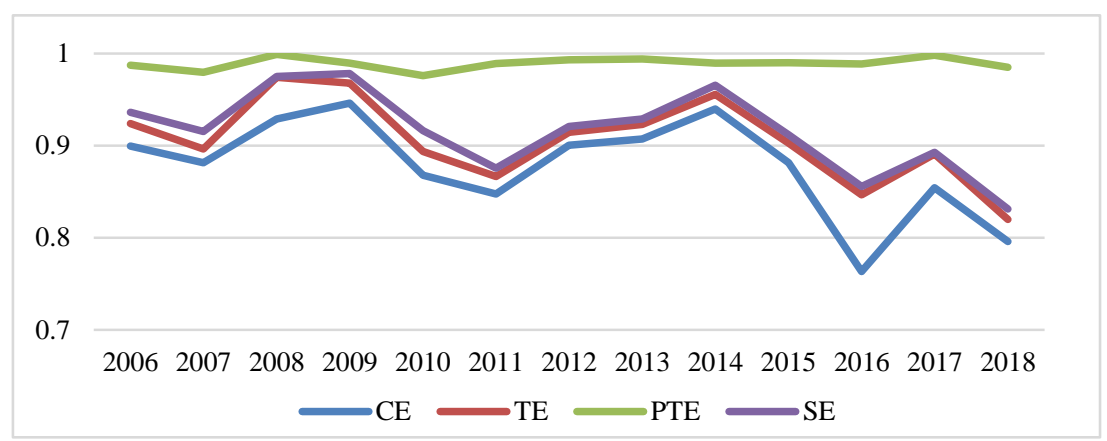

Figure 2. Cost efficiency (CE), Technical efficiency (TE), Pure technical efficiency (PTE), and Scale efficiency

(SE) trends

Table 2 shows the regression outputs when HHI and MS information are based on assets and deposits respectively. Regression 1 reveals that $\mathrm{HHI}_{\mathrm{a}}$ as proxy for industry concentration is negative and statistically insignificant, indicating the rejection of SCP construct. On the other hand, the $\mathrm{MS}_{\mathrm{a}}$ variable denoting market share is positive and statistically significant, suggesting support for RMP proposition. Because SCP and RMP are components of MPH, these findings signal partial support for MPH. Since SCP presumes that banks achieve high profitability by colluding (Hamid, 2017; Berger \& Hannan, 1998), the lack of support for SCP signifies absence of collusive behaviour in the Canadian banking industry, which is consistent with Allen and Engert (2007). Regression 2 with HHI and MS data based on deposits reveals similar findings. The evidence in support of RMP is similar to Ye, Xu, and Fang (2012) finding regarding the Chinese banking sector. It is also consistent with Garza-Garcia (2012) findings relating to the Mexican banking industry. However, it contradicts Alhassan, Tetteh, Brobbey (2016) outcomes concerning the Ghanaian banking industry. Nonetheless, the presence of RMP in the Canadian banking industry indicates that banks that differentiate on products and services attain better profitability than banks that do not. Such banks could accumulate market power and enlarge market share irrespective of the industry's concentration (Hamid, 2017; Fu \& Heffernan, 2009). Product and service differentiation that allow banks to charge higher price could be achieved through a combination of unique products and services, good brand image and reputation, and network of branches for customers' convenience (Kavale, Mugambi, \& Namusonge, 2016; Northcott, 2004).

Table 2. Regression output with Cost Efficiency (CE) as the X-efficiency (ESX) measure

\begin{tabular}{lclc}
\hline & $\begin{array}{c}\text { Regression } \\
\text { ROA }\end{array}$ & & Regression 2 \\
& -0.00028 & HHI $_{\mathrm{d}}$ & $-0.00205^{*}$ \\
$\mathrm{HHI}_{\mathrm{a}}$ & $0.00539^{*}$ & $\mathrm{MS}_{\mathrm{d}}$ & $0.00566^{*}$ \\
$\mathrm{MS}_{\mathrm{a}}$ & $0.71078^{*}$ & $\mathrm{CE}$ & 0.25565 \\
$\mathrm{CE}$ & $-1.52784^{*}$ & $\mathrm{SE}$ & $-1.27106^{*}$ \\
$\mathrm{SE}$ & -0.07193 & LLPTL & -0.05156 \\
LLPTL & $-0.40266^{*}$ & SREAD & -0.29164 \\
SPREAD & 0.00008 & CGDPPC & $0.00009^{*}$ \\
CGDPPC & $-0.01276^{*}$ & LOTD & -0.00767 \\
LOTD & $8.83906^{*}$ & EQTA & $10.0869^{*}$ \\
EQTA & $0.54550^{*}$ & SPREAD*LOTD & $0.41418^{*}$ \\
SPREAD*LOTD & 104 & Number of Obs & 104 \\
\hline Number of Obs & 224.62 & Wald chi2(10) & 306.23 \\
Wald chi2(10) & 0.0000 & Prob chi2 & 0.0000 \\
Prob $>$ Chi2 & 0.4611 & R Squared & 0.4791 \\
R Squared & 0.1849 & Root MSE & 0.1818 \\
Root MSE & & . & \\
\hline
\end{tabular}

Note. * Indicates statistical significance at 5 percent level (i.e., $p$ values $\leq 0.05$ ).

Concerning the ESH, Table 2 reveals that CE, which is the X-efficiency (ESX) variable, has a positive influence on profitability in Regression 1 and Regression 2 . However, while it is statistically significant in Regression 1, it is insignificant in Regression 2. SE as the scale efficiency (ESS) variable shows negative and statistically 
significant effect on profitability in the two regressions. Findings relating to SE offer no support for the scale efficiency component of ESH. The finding that CE has statistically significant positive association with profitability (Regression 1; Table 2), but positive and insignificant link with profitability (Regression 2; Table 2) suggests plausible evidence of X-efficiency (ESX), and partial support for ESH. The X-efficiency (ESX) finding is inconsistent with Doyran (2012) views relating to US financial institutions. Nonetheless, it supports Kapopoulos \& Siokis (2005) findings regarding Euro area banking industry. The plausible evidence of X-efficiency (ESX) could indicate that banks with better management and technology are able to control costs, leading to better profitability, enlarged market share, and a possible increase in the industry's concentration (Bucevska \& Misheva, 2017; Kapopoulos \& Siokis (2005). While these findings offer no support for the scale efficiency (ESS) component of ESH, the negative relationship between SE and profitability signifies that banks in the industry have not been able to increase profitability by adjusting operational scale. In the interim, scale adjustment may have resulted in high costs and decline in profitability. However, in the long run, it could improve profitability as banks are better able to respond to customers' needs. The observed partial support for ESH is tested using Model 5 and Model 6. To confirm the plausible ESH, the coefficients of CE, which is the $\mathrm{X}$-efficiency (ESX) variable and SE, which is the scale efficiency (ESS) variable in Model 5 and Model 6 have to be positive and statistically significant. The results of the tests in Table 3 reveal the outcome under $\mathrm{HHI}_{\mathrm{a}}$ and $\mathrm{MS}_{\mathrm{a}}$ and under $\mathrm{HHI}_{\mathrm{d}}$ and $\mathrm{MS}_{\mathrm{d}}$. The tests did not confirm ESH. The confirmation variables (i.e., CE \& SE) are either not significant or do not have the necessary signs in situations where they are significant (Table 3). Because the results show that the requisite tests to proof ESH are not satisfied, the projected partial support for ESH in the industry is tenuous, leading to its rejection.

Table 3. Efficiency Structure Hypothesis (ESH) test

\begin{tabular}{|c|c|c|c|c|}
\hline & \multicolumn{2}{|c|}{ Dependent Variables } & \multicolumn{2}{|c|}{ Dependent Variables } \\
\hline & $\mathrm{HHI}_{\mathrm{a}}$ & $\mathrm{MS}_{\mathrm{a}}$ & $\mathrm{HHI}_{\mathrm{d}}$ & $\mathrm{MS}_{\mathrm{d}}$ \\
\hline $\mathrm{CE}$ & -93.90963 & 0.48167 & $-225.2996^{*}$ & 3.83173 \\
\hline SE & $-263.6845^{*}$ & $-37.19855^{*}$ & 72.85803 & $-41.19273 *$ \\
\hline LLPTL & $-26.16548 *$ & $2.98352^{*}$ & 5.74600 & $2.63557^{*}$ \\
\hline SPREAD & 27.1802 & 8.57748 & $60.99886^{*}$ & 9.32533 \\
\hline CGDPPC & $-0.11084^{*}$ & 0.00075 & -0.00662 & 0.00102 \\
\hline LOTD & 1.62944 & 0.01417 & $2.72573 *$ & 0.02107 \\
\hline EQTA & $1667.292 *$ & 48.2551 & $849.821^{*}$ & 50.45251 \\
\hline SPREAD*LOTD & $-90.98143 *$ & $-14.27285^{*}$ & $-79.76835^{*}$ & $-14.78415^{*}$ \\
\hline Number of Obs & 104 & 104 & 104 & 104 \\
\hline Wald chi2(8) & 91.6 & 155.41 & 153.10 & 147.43 \\
\hline Prob $>$ chi 2 & 0.0000 & 0.0000 & 0.0000 & 0.0000 \\
\hline R Squared & 0.5783 & 0.4067 & 0.5082 & 0.4168 \\
\hline Root MSE & 48.004 & 6.9461 & 19.275 & 6.7776 \\
\hline
\end{tabular}

Note. $*$ Indicates statistical significance at 5 percent level (i.e., $p$ values $\leq 0.05$ ).

Table 4. Quiet life hypothesis (QLH) test

\begin{tabular}{lcclcc}
\hline & \multicolumn{2}{c}{ Dependent Variables } & & \multicolumn{2}{c}{ Dependent Variables } \\
& \multicolumn{2}{c}{ CE } & SE & & \multicolumn{2}{c}{ CE } & SE \\
\hline HHI $_{\mathrm{a}}$ & $-0.00063^{*}$ & $-0.00056^{*}$ & $\mathrm{HHI}_{\mathrm{d}}$ & $-0.00179^{*}$ & $-0.00111^{*}$ \\
$\mathrm{MS}_{\mathrm{a}}$ & $-0.0032^{*}$ & $-0.00310^{*}$ & $\mathrm{MS}_{\mathrm{d}}$ & $-0.00208^{*}$ & $-0.00248^{*}$ \\
LLPTL & 0.00705 & -0.00471 & LLPTL & 0.02521 & 0.01133 \\
SPREAD & $0.14696^{*}$ & 0.09168 & SPREAD & $0.21173^{*}$ & $0.13423^{*}$ \\
CGDPPC & -0.00004 & -0.00003 & CGDPPC & 0.00002 & 0.00003 \\
LOTD & $0.00565^{*}$ & $0.00379^{*}$ & LOTD & $0.00874^{*}$ & $0.00538^{*}$ \\
EQTA & $2.23912^{*}$ & $1.56814^{*}$ & EQTA & $2.45854^{*}$ & $1.47477^{*}$ \\
SPREAD*LOTD & $-0.19539^{*}$ & $-0.13617^{*}$ & SPREAD*LTD & $-0.24715^{*}$ & $-0.15894^{*}$ \\
\hline Number of Obs & 104 & 104 & Number of Obs & 104 & 104 \\
Wald chi2(8) & 197.26 & 242.53 & Wald chi2(8) & 159.83 & 127.05 \\
Prob > chi2 & 0.0000 & 0.0000 & Prob > chi2 & 0.0000 & 0.0000 \\
R Squared & 0.4813 & 0.4747 & R Squared & 0.5493 & 0.4380 \\
Root MSE & 0.06745 & 0.05471 & Root MSE & 0.06287 & 0.05659 \\
\hline
\end{tabular}

Note. $*$ Indicates statistical significance at 5 percent level (i.e., $p$ values $\leq 0.05$ ). 
Furthermore, the QLH was tested using Model 3 and Model 4. Table 4 reveals the result with $\mathrm{HHI}_{\mathrm{a}}$ and $\mathrm{MS}_{\mathrm{a}}$ information and $\mathrm{HHI}_{\mathrm{d}}$ and $\mathrm{MS}_{\mathrm{d}}$ data. The Table shows that HHI and MS have statistically significant negative effects on CE (i.e., X-efficiency [ESX]) and SE (i.e., scale efficiency [ESS]) variables. These findings show the presence of Hicks (1935, p. 8) "quiet life" hypothesis (QLH), which posits that as banks amass market power when industry concentration increases, managers can raise price and would exhibit no motivations to curtail costs (Lelissa \& Kuhil, 2017; Berger \& Hannan, 1998). The finding that QLH holds in the industry is consistent with Gavurova, Kocisova, and Kotaskova (2017) view of EU banking, Repkova and Stavarek (2013) outlook of the Czech banking industry, and Berger and Hannan (1998) assessment of the US banking industry. However, it contradicts Mensi \& Zouari (2010) and Casu and Giradone (2009) findings that show no support for QLH. Nonetheless, the finding that QLH holds in the case of Canada signifies that banks in the industry are able to exercise market power, charging higher rates on loans to customers and paying lower rates on deposits.

Given the similarities in signs of the control variables in Regression 1 and Regression 2 (Table 2), the discussion of the control variables focuses on Regression 1. Among the control variables, LLPTL as a measure of credit risk (Pervan, Pelivan, \& Arneric, 2016; Sharma, Gounder, \& Xiang, 2013) is negative and statistically insignificant, suggesting that it has no relevant effect on profitability of banks. While this finding aligns with Hamid (2017) observation, it contrasts Bucevska and Misheva (2017) report of a negative and statistically significant effect on profitability of banks. Spread (SPREAD) denotes the difference between the rate banks charge on loans to customers and the rate paid on deposits (Aboagye, 2012). It has a negative effect on profitability in the two regressions (Table 2). The finding that the effect is statistically significant in Regression 1 shows that spread could diminish profitability. To increase spread, banks may charge a higher lending rate, which increases the cost of borrowing (Saona, 2016). This could reduce incentive for new bank loans and cause profitability to decline. In addition, the negative impact of spread on profitability may reflect exposure of banks to losses if customers default due to the high rates on loan (Addae-Korankye, 2014). It is also possible for banks to increase spread by reducing rates on deposits, however, this makes deposits in banks unattractive to depositors (Soledad, Peria, \& Mody, 2004). The reduction in deposits could constrain banks' ability to make new loans, leading to profitability decline. Change in GDP per capita (CGDPPC), which denotes economic growth (Majumder \& Li 2018) has a positive link with profitability in Regression 1 and Regression 2 (Table 2). However, the impact on profitability in Regression 1 is statistically insignificant, implying that economic growth could be immaterial to the profitability of banks. While this finding refutes Ayaydin and Karakaya (2014) and Staikouras and Wood (2004) remarks that it undermines profitability, it is consistent with findings in Majumder and Li (2018) and Sharma, Gounder, and Xiang (2013) that show no effect on profitability. Although economic growth may result in more deposits with banks (Owen \& Pereira, 2018), it could be unimportant to profitability unless banks utilize the funds in new loans and profitable investments. While the focus is on Regression 1, the statistically significant positive influence in Regression 2 (Table 2) aligns with Goddard, Molyneux, and Wilson (2004). In addition, it corroborates Yao, Haris, and Tariq (2018) finding that improved economic conditions create demand for loans, leading to higher profitability. LOTD reflects liquidity risk and the ability of banks to convert deposits to loans (Kocisova, 2016; Yudaruddin, 2012). The two regressions reveal a negative association between LOTD and profitability. The finding that the negative effect is statistically significant in Regression 1 (Table 2) shows that increasing loan to deposit ratio could inhibit profitability. This observation substantiates Garza-Garcia (2012), but it contradicts Simatele, Mishi, and Ngonyama (2018) finding that indicate statistically significant positive influence on profitability. High LOTD reduces liquidity and creates the need for banks to raise funds at higher costs (Gropp, Sorensen, \& Lichtenberger, 2007), leading to profitability decline. EQTA, which is the proxy for capitalization (Kocisova, 2016) has a statistically significant positive effect on profitability. While this finding departs from Almumani (2013) remark that the effect is negative and statistically insignificant, it is consistent with findings in Bucevska and Misheva (2017) and Garza-Garcia (2012) that show that capitalization drives profitability. The positive effect on profitability indicates that banks with high capitalization will achieve better profitability. High capitalization reduces the risk of failure, conferring to banks benefits such as good reputation, and the ability to secure funds at low costs (Menicucci \& Paolucci, 2016). The interaction term (i.e., SPREAD*LOTD) has a positive and statistically significant impact on profitability, implying that the joint effect of the two variables is important to profitability.

\section{Robustness Check}

While this study adopts CE as X-efficiency (ESX) measure, other studies use either TE or PTE to reflect $\mathrm{X}$-efficiency (ESX). For this reason, the robustness checks when either TE or PTE replaces CE is necessary to determine if findings in this study are sensitive to parameter change. Similar to the original findings, the results of the robustness checks in Table 5 and Table 6 show that the MS variable is positive and statistically significant 
in each of the regressions, pointing to evidence of RMP in the industry. Additionally, the results in Table 5 and Table 6 provide no support for the ESH, making it unnecessary to perform further tests associated with ESH (Mensi \& Zouari, 2010). Nonetheless, in order to avoid wrong declaration, confirmation tests were performed. The test results in Table 7 and Table 8 show that the required conditions for ESH confirmation are not satisfied, signifying no evidence of ESH in the industry. In addition, the QLH test results with either TE or PTE as X-efficiency (ESX) variable (Table 9A and Table 9B) show that QLH holds in the industry. The $\mathrm{R}^{2}$ in the robustness checks are similar to the initial findings. These $\mathrm{R}^{2}$ are comparable to prior studies (e.g., Yuanita, 2019; Lelissa \& Kuhil, 2017, Guillen, Rengifo, Ozsoz, 2014; Sharma, Gounder, \& Xiang, 2013; Berger, 1995). The R² should not be a concern. This is because the motive is not to predict but to identify variables with influence on profitability (Guillen, Rengifo, \& Ozsoz, 2014). In general, the robustness checks reveal outcomes that are identical to the original results, thereby confirming the consistency of the findings in the study.

Table 5. Robustness check with Technical Efficiency (TE) as the X-efficiency (ESX)

\begin{tabular}{lclc} 
& Regression 3 & & Regression 4 \\
\hline HHI $_{\mathrm{a}}$ & ROA & & $-0.00231^{*}$ \\
$\mathrm{MS}_{\mathrm{a}}$ & -0.00033 & $\mathrm{HHI}_{\mathrm{d}}$ & $0.00623^{*}$ \\
$\mathrm{TE}$ & $0.00540^{*}$ & $\mathrm{MS}_{\mathrm{d}}$ & -0.41099 \\
$\mathrm{SE}$ & -0.08449 & $\mathrm{TE}$ & -0.61297 \\
LLPTL & -0.72756 & $\mathrm{SE}$ & -0.04592 \\
SPREAD & -0.06324 & LLPTL & -0.26183 \\
CGDPPC & -0.36235 & SREAD & $0.00009^{*}$ \\
LOTD & -0.00007 & CGDPPC & -0.00620 \\
EQTA & $-0.01114^{*}$ & LOTD & $10.57684^{*}$ \\
SPREAD*LOTD & 9.35162 & EQTA & 0.37763 \\
\hline Number of Obs & $0.50177^{*}$ & SPREAD*LOTD & 104 \\
Wald chi2(10) & 104 & Number of Obs & 316.23 \\
Prob > chi2 & 235.16 & Wald chi2 $(10)$ & 0.0000 \\
R Squared & 0.0000 & Prob chi2 ch & 0.4790 \\
Root MSE & 0.4492 & R Squared & 0.18181 \\
\hline
\end{tabular}

Note. * Indicates statistical significance at 5 percent level (i.e., $p$ values $\leq 0.05$ ).

Table 6. Robustness check with Pure Technical Efficiency (PTE) as the X-efficiency measure

\begin{tabular}{|c|c|c|c|}
\hline & $\begin{array}{c}\text { Regression } 5 \\
\text { ROA }\end{array}$ & & $\begin{array}{c}\text { Regression } 6 \\
\text { ROA }\end{array}$ \\
\hline $\mathrm{HHI}_{\mathrm{a}}$ & -0.00033 & $\mathrm{HHI}_{\mathrm{d}}$ & $-0.00230^{*}$ \\
\hline $\mathrm{MS}_{\mathrm{a}}$ & $0.00533^{*}$ & $\mathrm{MS}_{\mathrm{d}}$ & $0.006123^{*}$ \\
\hline PTE & -0.01206 & $\mathrm{TE}$ & -0.28894 \\
\hline SE & $-0.81460^{*}$ & SE & $-1.02382 *$ \\
\hline LLPTL & -0.06351 & LLPTL & -0.04621 \\
\hline SPREAD & -0.36334 & SREAD & 0.26303 \\
\hline CGDPPC & 0.00007 & CGDPPC & $0.00009^{*}$ \\
\hline LOTD & $-0.01121^{*}$ & LOTD & -0.00630 \\
\hline EQTA & $9.31908^{*}$ & EQTA & $10.52547^{*}$ \\
\hline SPREAD*LOTD & $0.50335^{*}$ & SPREAD*LOTD & 0.37974 \\
\hline Number of Obs & 104 & Number of Obs & 104 \\
\hline Wald chi2(10) & 234.26 & Wald chi2(10) & 314.82 \\
\hline Prob > chi2 & 0.0000 & Prob > chi 2 & 0.0000 \\
\hline R Squared & 0.4491 & R Squared & 0.4786 \\
\hline Root MSE & 0.18695 & Root MSE & 0.18188 \\
\hline
\end{tabular}

Note. * Indicates statistical significance at 5 percent level (i.e., $p$ values $\leq 0.05$ ). 
Table 7. Efficiency Structure Hypothesis (ESH) test with Technical efficiency (TE) as X-efficiency measure

\begin{tabular}{lcccc}
\hline & \multicolumn{2}{c}{ Dependent Variables } & \multicolumn{2}{c}{ Dependent Variables } \\
& $\mathrm{HHI}_{\mathrm{a}}$ & $\mathrm{MS}_{\mathrm{a}}$ & $\mathrm{HHI}_{\mathrm{d}}$ & $\mathrm{MS}_{\mathrm{d}}$ \\
\hline TE & $-274.8998^{*}$ & $109.3925^{*}$ & -109.5517 & $121.1722^{*}$ \\
SE & -83.48236 & $-146.9088^{*}$ & -48.8724 & $-159.3191^{*}$ \\
LLPTL & $-25.33375^{*}$ & $2.16595^{*}$ & 3.59921 & $1.77347^{*}$ \\
SPREAD & 28.45366 & 6.13066 & $51.62541^{*}$ & 6.78849 \\
CGDPPC & $-0.11115^{*}$ & 0.00101 & -0.00683 & 0.00131 \\
LOTD & 1.69133 & -0.08685 & $2.36133^{*}$ & -0.08399 \\
EQTA & $1744.153^{*}$ & -2.87814 & $775.8008^{*}$ & -4.34974 \\
SPREAD*LOTD & $-95.86189^{*}$ & -10.42624 & $-72.01351^{*}$ & -10.6936 \\
\hline Number of Obs & 104 & 104 & 104 & 104 \\
Wald chi2(8) & 82.16 & 228.13 & 106.68 & 218.04 \\
Prob > chi2 & 0.0000 & 0.0000 & 0.0000 & 0.0000 \\
R Squared & 0.5825 & 0.4766 & 0.4118 & 0.5060 \\
Root MSE & 47.759 & 6.524 & 21.079 & 6.2381 \\
\hline
\end{tabular}

Note. * Indicates statistical significance at 5 percent level (i.e., $p$ values $\leq 0.05$ ).

Table 8. Efficiency Structure Hypothesis (ESH) tests with Pure Technical Efficiency as X-efficiency measure

\begin{tabular}{|c|c|c|c|c|}
\hline & \multicolumn{2}{|c|}{ Dependent Variables } & \multicolumn{2}{|c|}{ Dependent Variables } \\
\hline & $\mathrm{HHI}_{\mathrm{a}}$ & $\mathrm{MS}_{\mathrm{a}}$ & $\mathrm{HHI}_{\mathrm{d}}$ & $\mathrm{MS}_{\mathrm{d}}$ \\
\hline PTE & $-258.2258^{*}$ & $96.08389 *$ & -95.02557 & $107.0281^{*}$ \\
\hline SE & $-355.6661^{*}$ & $-38.47404 *$ & $-157.487^{*}$ & $-39.21888 *$ \\
\hline LLPTL & $-25.1305^{*}$ & $2.14383^{*}$ & 3.61081 & $1.74371^{*}$ \\
\hline SPREAD & 29.06668 & 6.06311 & $51.66139 *$ & 6.69786 \\
\hline CGDPPC & $-0.11123^{*}$ & 0.00090 & -0.00672 & 0.00119 \\
\hline LOTD & 1.70973 & -0.08707 & $2.36028^{*}$ & -0.08487 \\
\hline EQTA & $1744.387 *$ & 0.37304 & $771.9445^{*}$ & -1.04796 \\
\hline SPREAD*LOTD & $-96.52337 *$ & -10.43154 & $-71.9600 *$ & -10.67543 \\
\hline Number of Obs & 104 & 104 & 104 & 104 \\
\hline Wald Chi2(8) & 85.06 & 226.28 & 106.66 & 219.04 \\
\hline Prob > Chi2 & 0.0000 & 0.0000 & 0.0000 & 0.0000 \\
\hline R Squared & 0.5834 & 0.4755 & 0.4115 & 0.5055 \\
\hline Root MSE & 47.71 & 6.5313 & 21.084 & 6.2411 \\
\hline
\end{tabular}

Note. * Indicates statistical significance at 5 percent level (i.e., $p$ values $\leq 0.05$ ).

Table 9A. Robustness check indicating QLH with TE and PTE as X-efficiency measure

\begin{tabular}{|c|c|c|c|}
\hline & \multicolumn{3}{|c|}{ Dependent Variables } \\
\hline & $\mathrm{TE}$ & PTE & $\mathrm{SE}$ \\
\hline $\mathrm{HHI}_{\mathrm{a}}$ & $-0.00061 *$ & -0.00006 & $-0.00056^{*}$ \\
\hline $\mathrm{MS}_{\mathrm{a}}$ & $-0.00217 *$ & $0.00100 *$ & $-0.00310^{*}$ \\
\hline LLPTL & -0.00110 & 0.00427 & -0.00471 \\
\hline SPREAD & 0.10926 & 0.02173 & 0.09168 \\
\hline CGDPPC & -0.00004 & $-7.32 \mathrm{e}^{-06}$ & -0.00003 \\
\hline LOTD & $0.00456^{*}$ & $0.00126^{*}$ & $0.00379 *$ \\
\hline EQTA & $2.08325^{*}$ & $0.57725^{*}$ & $1.56814^{*}$ \\
\hline SPREAD*LOTD & $-0.16375^{*}$ & $-0.03310^{*}$ & $-0.13617^{*}$ \\
\hline Number of Obs & 104 & 104 & 104 \\
\hline Wald chi2(8) & 178.64 & 21.04 & 242.53 \\
\hline Prob > chi2 & 0.0000 & 0.0071 & 0.0000 \\
\hline R Squared & 0.4497 & 0.2128 & 0.4747 \\
\hline Root MSE & 0.06039 & 0.02359 & 0.05471 \\
\hline
\end{tabular}

Note. * Indicates statistical significance at 5 percent level (i.e., $p$ values $\leq 0.05$ ). 
Table 9B. Robustness check indicating QLH with TE and PTE as X-efficiency measure

\begin{tabular}{lccc}
\hline & & Dependent Variables & SE \\
\hline HHI $_{\mathrm{d}}$ & TE & PTE & $-0.00111^{*}$ \\
MS $_{\mathrm{d}}$ & $-0.00128^{*}$ & $-0.00020^{*}$ & $-0.00248^{*}$ \\
LLPTL & -0.00129 & $0.001316^{*}$ & 0.01133 \\
SPREAD & 0.01619 & 0.00591 & $0.13423^{*}$ \\
CGDPPC & $0.15579^{*}$ & 0.02654 & 0.00003 \\
LOTD & 0.00002 & $-2.68 \mathrm{e}^{-06}$ & $0.00538^{*}$ \\
EQTA & $0.00676^{*}$ & $-0.00162^{*}$ & $1.47477^{*}$ \\
SPREAD*LOTD & $2.02428^{*}$ & $0.60455^{*}$ & $-0.15894^{*}$ \\
\hline Number of Obs & $-0.18971^{*}$ & -0.03654 & 104 \\
Wald chi2(8) & 104 & 104 & 127.05 \\
Prob > chi2 & 112.62 & 22.45 & 0.0000 \\
R Squared & 0.0000 & 0.0042 & 0.4380 \\
Root MSE & 0.4217 & 0.2547 & 0.05659 \\
\hline
\end{tabular}

Note. * Indicates statistical significance at 5 percent level (i.e., $p$ values $\leq 0.05$ ).

\section{Conclusion}

This study examines profitability in the Canadian banking industry and tests the two competing hypotheses (i.e., MPH \& ESH). The HHI level indicates that the industry is somewhat concentrated, suggesting that banks have market power, however, concentration does not preclude competition (Claessens \& Laeven, 2004). The tendency for competition in the industry is buttressed by finding no support for SCP. This signifies no evidence that banks in the industry attain better profitability by colluding on rates and fees. The support for RMP, which shows that banks achieve profitability by offering differentiated products and services harmonize with prior empirical studies including Pawłowska (2016), Sharma, Gounder, and Xiang (2013), and Garza-Garcia (2012). Nonetheless, the moderate level of concentration signals that banks in the industry possess some market power. To prevent implicit collusion, regulatory policy should ensure that banks are transparent when setting rates and fees. The finding that $\mathrm{CE}$ (i.e., X-efficiency $[\mathrm{ESX}]$ ) variable enhances profitability seems to provide partial support for ESH. However, because the requisite tests failed to confirm ESH, the purported partial support for ESH is unfounded, necessitating its rejection. The finding that QLH holds in the industry suggests that managers exercise market power, and display suboptimal behaviours by foregoing revenue increase and/or cost minimization opportunities (Subramaniam, Ab-Rahim, \& Selvarajan, 2019; Berger \& Hannan, 1998; Hicks, 1935). In view of this, banks need to establish proper monitoring mechanism to dissuade managers from engaging in behaviours that undermine efficient operations. Furthermore, the finding that QLH holds in the industry and the potential efficiency loss should concern regulators. Regulators need to aim at increasing the level of competition in the industry. The increase in competition could motivate managers to improve resource allocation, spur product and service innovations, and ensure access to better services and rates (Ab-Rahim, 2016).

Credit risk as denoted by LLPTL appears to have unimportant negative effect on profitability. Although unimportant, the negative relationship suggests that banks should not ignore credit risk management (Saona, 2016). As part of credit risk management, banks should properly screen loan applicants to reduce the likelihood of defaults and profitability decline (Muhamet \& Arbana, 2016). The finding that spread impedes profitability signifies the need for banks not to pursue profitability objectives by arbitrarily increasing rates on loans, or decreasing rates on deposits. In addition, regulators need to ensure that rules that banks set are fair to customers. Because macroeconomic factors affect spread (Soledad, Peria, \& Mody, 2004), government policy makers need to ensure that policy objectives are not contributing to spread increase. The findings relating to economic growth reveal that unless banks make new loans and profitable investments during economic growth, profitability may not increase. Liquidity risk as reflected by high loan to deposit (LOTD) ratio is detrimental to profitability. It could leave banks with insufficient funds, which undermines the ability to meet new loan requests or unplanned withdrawals by customers (Gropp, Sorensen, \& Lichtenberger, 2007). Also, it could create the need for banks to close funding gaps with high cost funds, leading to profitability decline (Gropp, Sorensen, \& Lichtenberger, 2007). To reduce exposure to liquidity risk, regulators need to ensure that banks are able to meet funding requirements. In addition, banks need to be amenable to investing in high liquid assets, which are convertible to cash to meet anticipated funding needs (Hlebik \& Ghillani, 2017). The finding that capitalization improves 
profitability shows that adequately capitalized banks will achieve better profitability than less capitalized banks. This is possible because adequately capitalized banks are able to attract funds at low costs (Menicucci \& Paolucci, 2016). However, because the strong position and ability to tolerate losses could move highly capitalized banks to take on risky ventures (Amin, Ali, \& Nor, 2018), it is important that banks be monitored for compliance with capital requirements and prudential regulations. The positive effect of the interaction term (i.e., SPREAD*LOTD) shows that the joint effect of spread and liquidity risk is important to the profitability of banks. With the insights in this study, managers in the industry are better prepared to pursue profitability objectives in ways consistent with the industry's structure and regulatory frameworks. Additionally, this empirical study provides policy makers better understanding of the industry. With evidence supporting RMP, it is apparent that profitability could be achieved by offering differentiated products and services. This would require innovation and/or diversification into non-traditional banking services that complement existing products and services. As banks face competition from other markets (Northcott, 2004), future research should examine how this affects the behaviour and decisions of managers in the industry. Additionally, relying on the HHI guideline in US Department of Justice and Trade Commission (2010), this study finds the Canadian banking industry to be somewhat concentrated. The views in Ertl and McCarrell (2002) would have resulted in declaring the industry as perfectly competitive, whereas the opinions in Djov (2013) and Ferreira (2013) would have led to the decision that the industry reflects an oligopoly or highly concentrated structure. To ascertain the structure of the industry and the implications for banks, future research should consider using the Lener Index or Panzar-Rosse model.

\section{References}

Aboagye, A. Q. Q. (2012). Bank concentration and economic costs of deposit mobilization and credit extensions in Ghana. The Journal of Developing Areas, 46(2), 351-370. https://doi.org/10.1353/jda.2012.0023

Ab-Rahim, R. (2016). Does competition foster efficiency? Empirical evidence form Malaysian commercial banks. Asian Academy of Management Journal of Accounting \& Finance, 12(1), 1-23.

Addae-Korankye, A. (2014). Causes and control of loan default/delinquency in microfinance institutions in Ghana. American International Journal of Contemporary Research, 4(12), 36-45.

Ajlouni, M. M. (2010). The main features of the structure-conduct-performance (SCP) literature in banking during the 1960s and 1980s. International Journal of Economic Perspectives, 4(3), 509-523.

Aktan, B., \& Masood, O. (2010). The state of competition of the Turkish banking industry: An application of The Panzar-Rosse model. Journal of Business and Management, 11(1), 131-145. https://doi.org/10.3846/jbem.2010.07

Allen, J., \& Engert, W. (2007). Efficiency and competition in Canadian banking. Bank of Canada Review, Summer2007. Retrieved on November 3, $2019 . \quad$ From https://www.bankofcanada.ca/wp-content/uploads/2010/06/allen-engert.pdf

Alhassan, A. L., Tetteh, M. L., \& Brobbey, F. O. (2016). Market power, efficiency and bank profitability: evidence from Ghana. Economic Change and Restructuring, 49(1), 71-93. https://doi.org/10.1007/s10644-015-9174-6

Al-Muharrami, S., \& Matthews, K. (2009). Market power versus efficient-structure in Arab GCC banking. Applied Financial Economics, 19(18), 1487-1496. https://doi.org/10.1080/09603100902845478

Almumani, M. A. (2013). Impact of managerial factors on commercial bank profitability: Empirical evidence from Jordan. International Journal of Academic Research in Accounting, Finance and Management Sciences, 3(3), 298-310. https://doi.org/10.6007/IJARAFMS/v3-i3/203

Amin, S., I., M., Ali, M., H., \& Nor, S. M. (2018). Cost efficiency and liquidity risk in banking: New evidence from OIC countries. International Journal of Business and Management Science, 8(2), 255-276.

Antoun, R., Coskun, A., \& Georgievski, B. (2018). Determinants of financial performance of banks in central and eastern Europe. Business and Economic Horizon, 14(3), 513-529. https://doi.org/10.15208/beh.2018.37

Ayadi, I., \& Ellouze, A. (2013). Market structure and performance of Tunisian banks. International Journal of Economics and Financial Issues, 3(2), 345-354.

Ayaydin, H., \& Karakaya, A. (2014). The effect of bank capital on profitability and risk in Turkish banking. International Journal of Business and Science Research, 5(1), 252-271.

Babic, A., Zildzovic, E., \& Loncar, D. (2015).Testing for competition in Serbian banking industry: The Panzar-Rosse approach. Industrija, 43(3), 7-26. https://doi.org/10.5937/industrija43-7648 
Behname, M. (2012). The compare of concentration and efficiency in banking industry: Evidence from the OPEC countries. Eurasian Journal of Business and Economics, 5(10), 15-24.

Berger, A. (1995). The profit-structure relationship in banking--Tests of market-power and efficient-structure hypotheses. Journal of Money, Credit and Banking, 27(2), 404-431. https://doi.org/10.2307/2077876

Berger, A. N., Demirgug-Kunt, A., Levine, R., \& Haubrich, J. G. (2004). Bank concentration and competition: An evolution in the making. The Journal of Money, Credit, and Banking, 36(3 part 2), 433-451. https://doi.org/10.1353/mcb.2004.0040

Berger, A., \& Hannan, T. (1998). The efficiency cost of market power in the banking industry: A test of the "quiet life" and related hypotheses. The Review of Economics and Statistics, 80(3), 454-465. https://doi.org/10.1162/003465398557555

Bhatti, G. A., \& Hussain, H. (2010). Evidence on structure conduct performance hypothesis in Pakistani commercial banks. International Journal of Business and Management, 5(9), 174-187. https://doi.org/10.5539/ijbm.v5n9p174

Bikker, J. A., Shaffer, S., \& Spierdijk, L. (2012). Assessing competition with the Panzar-Rosse model: The role of scale, costs, and equilibrium. The Review of Economics and Statistics, 94(4), 1025-1044. https://doi.org/10.1162/REST_a_00210

Bucevska, V., \& Misheva, B. H. (2017). The determinants of profitability in the banking industry: Empirical research on selected Balkan countries. Eastern European Economics, 55(2), 146-167. https://doi.org/10.1080/00128775.2016.1260473

Casu, B., \& Giradone, C. (2006). Bank competition and efficiencies in the single European market. The Manchester School, 74(4), 441-468. https://doi.org/10.1111/j.1467-9957.2006.00503.x

Casu, B., \& Girardone, C. (2009). Testing the relationship between competition and efficiency in banking: A panel data analysis. Economics Letters, 105(1), 134-137. https://doi.org/10.1016/j.econlet.2009.06.018

Chortareas, G. E., Garza-Garcia, J. G., Girardone, C. (2010). Banking sector performance in some Latin American countries: Market power versus efficiency, Working Papers, No. 2010-20, Banco de México, Ciudad de México. Retrieved on January 3, 2020 from https://www.econstor.eu/bitstream/10419/83769/1/642536333.pdf

Claessens, S., \& Laeven, L. (2004). What drives bank competition? Some international evidence. Journal of Money, Credit, and Banking, 36(3), 563-583. https://doi.org/10.1353/mcb.2004.0044

Dabbous, A., Nassereddine, A. (2017). Consolidation, market concentration, and the performance of Lebanese commercial banks. International Journal of Economic Perspective, 11(2), 74-86.

Daniel, F. (2003). Recent changes to Canada's financial sector legislation. Bank of Canada Review, Winter 2002-2003, 3-14. Retrieved on December 18, 2019 from https://www.bankofcanada.ca/wp-content/uploads/2010/06/daniele.pdf

Demirel, O., \& Hatirli, S., A. (2017). Measuring the market power of the banking sector in Turkey. Journal of Academic Researches and Studies, 9(16), 20-34. https://doi.org/10.20990/kilisiibfakademik.307193

Demsetz, H. (1973). Industry structure, market rivalry, and public policy. The Journal of Law \& Economics, 16(1), 1-9. https://doi.org/10.1086/466752

Department of Finance Canada (2016). Supporting a strong and growing economy: Positioning Canada's financial sector for the future: A consultation document for the review of the federal financial sector framework. Ottawa, Ontario: Department of Finance Canada. Retrieved on October 4, 2019 from https://www.fin.gc.ca/activty/consult/ssge-sefc-eng.pdf

Djolov, G. (2013). The Herfindahl-Hirschman Index as a decision guide to business concentration: A statistical exploration. Journal of Economic and Social Measurement, 38(3) 201-227. https://doi.org/10.3233/JEM-130379

Doyran, M. A. (2012). The impact of market structures on financial institutions performance. Proceedings ASBBS, 19(1), 247-262.

Ertl, H., \& McCarrell, H. (2002). The State of telecommunications services. Ottawa, Ontario: Industry Canada.

Fare, R., Grosskopf, S., Maudos, J., \& Tortosa-Ausina, E. (2015). Revisiting the quiet life hypothesis in banking using nonparametric techniques. Journal of Business Economics and Management, 16(1), 159-187. 
https://doi.org/10.3846/16111699.2012.726929

Ferreira, C. (2013). Bank market concentration and bank efficiency in the European Union: A panel granger causality approach. International Economics \& Economic Policy, 10(3), 365-391. https://doi.org/10.1007/s10368-013-0234-y

Fu, X. M., \& Heffernan, S. (2009). The effects of reform on China's bank structure and performance. Journal of Banking \& Finance, 33(1), 39-52. https://doi.org/10.1016/j.jbankfin.2006.11.023

Garza-Garcia, J. G. (2012). Does market power influence bank profits in Mexico? A study on market power and efficiency. Applied Financial Economics, 22(1), 21-32. https://doi.org/10.1080/09603107.2011.595681

Gavurova, B., Kocisova, K., \& Kotaskova, A. (2017). The structure-conduct-performance paradigm in the $\begin{array}{lllll}\text { European Union } & \text { banking. Economics \& } & \text { Society, } & \text { 10(4), }\end{array}$ https://doi.org/10.14254/2071-789X.2017/10-4/8

Gischer, H., \& Stiele, M. (2008). Competition test with a non-structural model: The Panzar-Rosse method applied to German savings banks. German Economic Review, 10(1), 50-70. https://doi.org/10.1111/j.1468-0475.2008.00441.x

Goddard, J., Molyneux, P., \& Wilson, J. O. S. (2004). Dynamics of growth and profitability in banking. Journal of Money, Credit and Banking, 36(4), 1069-1090. https://doi.org/10.1353/mcb.2005.0015

Gropp, R., Sorensen, C. K., \& Lichtenberger, J. (2007). The dynamics of bank spreads and financial structure. Working Paper Series No. 714, Frankfurt, Germany: European Central Bank. Retrieved on December 23, 2019 from https://www.ecb.europa.eu/pub/pdf/scpwps/ecbwp714.pdf

Guillen, J., Rengifo, E. W., Ozsoz, E. (2014). Relative power and efficiency as a main determinant of banks' profitability in Latin America. Borsa Istanbul Review, 14(2), 119-125. https://doi.org/10.1016/j.bir.2014.02.003

Gunes, N., \& Yilmaz, A. (2016). Determinants of the efficiencies in Turkish banking sector. International Journal of Economics and Finance, 8(2), 215-225. https://doi.org/10.5539/ijef.v8n2p215

Hamid, F. S. (2017). The effect of market structure on banks' profitability and stability: Evidence from ASEAN-5 countries. International Economic Journal, 31(4), 578-598. https://doi.org/10.1080/10168737.2017.1408668

Hicks, J. R. (1935). Annual survey of economic theory: The theory of monopoly. Econometrica, 3(1), 1-20. https://doi.org/10.2307/1907343

Hlebik, S., \& Ghillani, L. (2017). Management strategies for bank's liquidity risk. International Journal of Economics and Finance, 9(6), 98-110. https://doi.org/10.5539/ijef.v9n6p98

International Monetary Fund (IMF) (2006). Financial soundness indicators: Compilation guide. Washington, D.C: $\begin{array}{llllll}\text { USA. } & \text { Retrieved } & \text { on } & \text { December } & \text { 18, }\end{array}$ https://www.imf.org/external/pubs/ft/fsi/guide/2006/pdf/fsiFT.pdf

Isik, I., \& Hassan, M. K. (2002). Technical, scale and allocative efficiencies of Turkish banking industry. Journal of Banking \& Finance, 26(4), 719-766. https://doi.org/10.1016/S0378-4266(01)00167-4

Kapopoulos, P., \& Siokis, F. (2005). Market structure, efficiency and rising consolidation of the banking industry in the Euro area. Bulleting of Economic Research, 57(1), 0307-3378. https://doi.org/10.1111/j.1467-8586.2005.00215.x

Kavale, S., Mugambi, F., \& Namusonge, G. (2016). The effect of product differentiation strategy on corporate growth in selected microfinance institutions in Kenya. International Journal for Research in Business, Management and Accounting, 2(6), 13-28.

Kocisova, K. (2016). Market structure and banking sector performance. Journal of Applied Economic Sciences (JAES), 11(4), 708-711.

Kuzucu, S. (2015). Concentration and competition in Turkish banking industry: The evidence from 2000 to 2012. International Journal of Finance \& Banking Studies, 4(3), 1-10. https://doi.org/10.20525/.v4i3.220

Lelissa, T. B., \& Kuhil, A. M. (2017). The impact of industry structure on performance and testing the "quiet life" hypothesis in the Ethiopian banking sector. The International Journal of Business and Management, 5(7), 151-171.

Lelissa, T. B., \& Kuhil, A. M. (2018). Empirical evidences on structure-conduct-performance relationship in the 
banking sector - A systematic review of literature. Global Journal of Management and Business Research, $18(3), 34-47$.

Lu, Y., Fung, H., \& Jiang, X. (2007). Market structure and profitability of Chinese commercial banks. The Chinese Economic Review, 40(5), 100-113. https://doi.org/10.2753/CES1097-1475400506

Majumder, M. T. H., \& Li, X. (2018). Bank risk and performance in an emerging market setting: The case of Bangladesh. Journal of Economics, Finance and Administrative Science, 23(46), 199-229. https://doi.org/10.1108/JEFAS-07-2017-0084

Mendes, V., \& Rebelo, J. (2003). Structure and performance in the Portuguese banking industry in the nineties. Portuguese Economic Journal, 2(1), 53-68. https://doi.org/10.1007/s10258-002-0016-5

Menicucci, E., \& Paolucci, G. (2016). Factors affecting bank profitability in Europe: An empirical investigation. African Journal of Business Management, 10(17), 410-420. https://doi.org/10.5897/AJBM2016.8081

Mensi, S. (2010). Measurement of competitiveness degree in Tunisian deposit banks: An application of the Panzar and Rosse model. Panoeconomicus 57(2), 189-207. https://doi.org/10.2298/PAN1002189M

Mensi, S., \& Zouari, A. (2010). Efficient structure versus market power: Theories and empirical evidence. International journal of Economics and Finance, 2(4), 151-166. https://doi.org/10.5539/ijef.v2n4p151

Mensi, S., \& Zouari, A. (2011). Banking industry, market structure and efficiency: The revised model of intermediary hypotheses. International Journal of Economics and Research, 2(1), 23-36. https://doi.org/10.5539/ijef.v2n4p151

Molyneux, P., \& Forbes, W. (1995). Market structure and performance of European banks. Applied Economics, 27(2), 155-159. https://doi.org/10.1080/00036849500000018

Muhamet, A., \& Arbana, S. (2016). The effect of credit risk management on banks' profitability in Kosovo. European Journal of Economic Studies, 18(4), 492-515. https://doi.org/10.13187/es.2016.18.492

Mustafa, A., \& Toci, V. (2017). Estimation of the banking sector competition in the CEE countries: The PanzarRosse approach. Zb. rad. Ekon. fak. Rij. 35(2), 459-485. https://doi.org/10.18045/zbefri.2017.2.459

Nabieu, G. A. A. (2013). The structure, conduct and performance of commercial banks in Ghana. European Journal of Business and Innovation Research, 1(4), 34-47.

Nathan, A., \& Neave, E. H. (1989). Competition and contestability in Canada's financial system: Empirical results. Canadian Journal of Economics, 22(3), 576-594. https://doi.org/10.2307/135541

Nguyen, H. P. (2019). Profitability of Vietnamese banks under competitive pressure. Emerging Markets Finance \& Trade, 55(9), 2004-2021. https://doi.org/10.1080/1540496x.2018.1511977

Northcott, C. A. (2004). Competition in banking: A review of the literature. Working Paper 2004-24 / Document de travail 2004-24. Bank of Canada. Retrieved on December 17, 2019 from https://www.bankofcanada.ca/wp-content/uploads/2010/02/wp04-24.pdf

OECD (2010). Policy roundtable: Competition, concentration and stability in the banking sector. Retrieved on December 17, 2019 from http://www.oecd.org/regreform/sectors/46040053.pdf

Oredegbe, A. (2020). Cost efficiency determinants: Evidence from the Canadian banking industry. International Journal of Business and Management, 15(1), 86-98. https://doi.org/10.5539/ijbm.v15n1p86

Owen, A. L., \& Pereira, J. M. (2018). Bank concentration, competition, and financial inclusion. Review of Development finance, 8(1), 1-17. https://doi.org/10.1016/j.rdf.2018.05.001

Pawłowska, M. (2016). Market structure, business cycle and bank profitability: Evidence on Polish banks. Banki Kredyt, (Bank \& Credit) 47(4), 341-364.

Pervan, M., Pelivan, I., \& Arneric, J. (2016). Profit persistence and determinants of bank profitability in Croatia. $\begin{array}{llll}\text { Economic } \quad \text { Research-Ekonomska } & \text { Istrazivanja, }\end{array}$ https://doi.org/10.1080/1331677X.2015.1041778

Qayyum, A., Mehmood, O., Kasheer, M., \& Haider, J. (2018). Determinants of performance in banking sector: Evidence from international markets. International Journal of Business and Management, 8(3), 549-565

Repkova, I., \& Stavarek, D. (2013). Relationship between competition and efficiency in the Czech banking industry. Acta Universitatis Agriculturae et Silviculturae Mendelianae Brunensis, 61(7), 2701-2707. http://dx.doi.org/10.11118/actaun201361072701 
Rodriguez, T. G., Bolivar, H. R., \& Reyes, A. Z. (2018). Competition and market structure of the banking sector in Mexico. Contaduría y Administración 63 (1), 1-21. https://doi.org/10.22201/fca.24488410e.2018.871

Saona, P. (2016). Intra- and extra-bank determinants of Latin American banks' profitability. International Review of Economics and Finance, 45, 197-214. https://doi.org/10.1016/j.iref.2016.06.004

Sathye, S., \& Sathye, M. (2004). Structure, conduct and performance relationship in Indian banking. Journal of Indian School of Political Economy, 16(1), 1-11.

Savage, L. (2014). From trial to triumph: How Canada's past financial crises helped shape a superior regulatory system. The School of Public Policy (SPP) Research Papers, 7(15), 1-59.

Seelanatha, L. (2010). Market structure, efficiency and performance of banking industry in Sri Lanka. Banks and Bank Systems, 5(1), 20-31.

Shaffer, S. (1993). A test of competition in Canadian banking. Journal of Money, Credit, and Banking, 25(1), 49-61. https://doi.org/10.2307/2077819

Sharma, P., Gounder, N., \& Xiang, D. (2013). Foreign banks, profits, market power and efficiency in PICs: Some evidence from Fiji. Applied Financial Economics, 23(22), 1733-1744. https://doi.org/10.1080/09603107.2013.848026

Short, B. K. (1979). The relation between commercial bank profit rates and banking concentration in Canada, Western Europe, and Japan. Journal of Banking and Finance, 3(3), 209-219. https://doi.org/10.1016/0378-4266(79)90016-5

Simatele, M., Mishi, S., \& Ngonyama, N. (2018). Structure and profitability in the banking sector. Banks and Bank Systems, 13(1), 49-59. https://doi.org/10.21511/bbs.13(1).2018.05

Soledad, M., Peria, M., \& Mody, A. (2004). How foreign participation and market concentration impact bank spreads: Evidence from Latin America. Journal of Money, Credit and Banking, 36(3) (Part 2), 511-537. https://doi.org/10.1353/mcb.2004.0048

Staikouras, C. K., \& Wood, G. E. (2004). The determinants of European bank profitability. International business and economics research journal, 3(6), 57-68. https://doi.org/10.19030/iber.v3i6.3699

Subramaniam, R. V. P., Ab-Rahim, R., \& Selvarajan, S. K. (2019). Financial development, efficiency, and competition of ASEAN banking market. Asia-Pacific Social Science Review, 19(3), 185-202.

Tregenna, F. (2009). The fat years: The structure and profitability of the US banking sector in the pre-crisis period. Cambridge Journal of Economics, 33(4), 609-632. https://doi.org/10.1093/cje/bep025

Ullah, S., Akhtar, P., Zaefarian, G. (2018). Dealing with endogeneity bias: The generalised methods of moments $\begin{array}{lllll}(\mathrm{GMM}) & \text { for } & \text { Panel data. Industrial Marketing } & \text { Management, } & 71,\end{array}$ https://doi.org/10.1016/j.indmarman.2017.11.010

U.S. Department of Justice and the Federal Trade Commission (2010). Horizontal merger guidelines. Retrieved on December $\quad 15, \quad 2019$ from https://www.ftc.gov/sites/default/files/attachments/merger-review/100819hmg.pdf

Yao, H., Haris, M., \& Tariq, G. (2018). Profitability determinants of financial institutions: Evidence from banks in Pakistan. International Journal of Financial Studies, 6(2), 1-28. https://doi.org/10.3390/ijfs6020053

Ye, Q., Xu, Z., \& Fang, D. (2012). Market structure, performance, and efficiency of the Chinese banking sector. Economic Change and Restructuring, 45(4), 337-358. https://doi.org/10.1007/s10644-012-9123-6

Yuanita, N. (2019). Competition and bank profitability. Journal of Economic Structures, 8(31), 1-15. https://doi.org/10.1186/s40008-019-0164-0

Yudaruddin, R. (2012). Market structure, conduct and performance: Evidence from Indonesia Banking industry. $\begin{array}{llll}\text { Ekuitas: Jurnal } & \text { Ekonomi dan } & \text { Keuangan, }\end{array}$ https://doi.org/10.24034/j25485024.y2015.v19.i3.1770

\section{Copyrights}

Copyright for this article is retained by the author(s), with first publication rights granted to the journal.

This is an open-access article distributed under the terms and conditions of the Creative Commons Attribution license (http://creativecommons.org/licenses/by/4.0/). 